\title{
PENGEMBANGAN MODUL TERINTEGRASI PENDIDIKAN KARAKTER PADA MATERI KOLOID
}

\author{
Nensia Viorita*, Betty Holiwarni, Erviyenni \\ Program Studi Pendidikan Kimia,Fakultas Keguruan dan Ilmu Pendidikan Universitas \\ Riau,Kampus Binawidya KM 12,5, Pekanbaru 28293, Riau, Indonesia
}

\begin{tabular}{l}
\hline \multicolumn{1}{c}{ Informasi Artikel } \\
\hline Sejarah Artikel: \\
Diterima 30 Maret 2019 \\
Disetujui 19 Juli 2019 \\
Dipublikasikan 25 Juli 2019 \\
\hline Keywords: \\
Module, \\
Character Education, \\
Colloidal Subject \\
\hline
\end{tabular}

\begin{abstract}
Abstrak
Penelitian ini bertujuan untuk mengembangkan modul terintegrasi pendidikan karakter pada materi koloid. Penelitian pengembangan menggunakan model 4-D yang memiliki 4 tahap yaitu, Define, Design, Develop dan Disseminate. Penelitian hanya dilakukan sampai pada tahap Develop. Validitas modul dinilai dengan 4 aspek, yaitu aspek kelayakan isi, aspek kebahasaan, aspek penyajian dan aspek kegrafisan. Untuk melihat kepraktisan modul dilakukan uji terbatas di dua sekolah, yaitu SMAN 5 Pekanbaru dan MA Darel Hikmah Pekanbaru. Hasil penilaian yang dilakukan oleh 3 validator menyatakan bahwa modul valid dengan persentase rata-rata sebesar $91,59 \%$. Hasil angket terbatas pada 30 orang peserta didik adalah 97,17\% dan hasil respons dari 2 orang guru kimia adalah 95,83\%. Berdasarkan hasil validasi dan uji terbatas, modul terintegrasi pendidikan karakter pada materi koloid dinyatakan valid dan praktis.
\end{abstract}

\begin{abstract}
This study was designed to develop an integrated module of character education in colloidal subject. Development research uses a 4-D model that has 4 stages, namely, Define, Design, Develop and Disseminate. The research was only carried out until the Development stage. The validity of the module was discussed 4 aspects, namely aspects of content feasibility, linguistic aspects, presentation aspects and graphic aspects. To see the practicality module, the limited testing was carried out to two schools, namely SMAN 5 Pekanbaru and MA Darel Hikmah Pekanbaru. The results of the assessment carried out by 3 validators state that the module was valid with an average percentage of $91.59 \%$. The results of the questionnaire were limited to 30 students, $97.17 \%$, while the response results from 2 chemistry teachers were $95.83 \%$. Based on the results of limited validation and testing, the integrated module of character education in colloidal subject was declared valid and practical.
\end{abstract}

(C) 2019 Universitas Riau

*Alamat korespondensi: Viorotaa83@gmail.com

\section{PENDAHULUAN}

Kurikulum berbasis karakter telah dikembangkan pada tingkat satuan pendidikan dan diprioritaskan pada kurikulum K13 dengan memunculkan kompetensi-kompetensi dasar untuk setiap aspek, meliputi: sikap spiritual (KI 1), sikap sosial (KI 2), pengetahuan (KI 3), 


\section{Jurnal Pendidikan Kimia Universitas Riau 2019 4(2): 27-35}

https://ejournal.unri.ac.id/index.php/JPKUR

dan keterampilan (KI 4). K13 diharapkan mampu mengembangkan karakter generasi penerus bangsa ke arah yang lebih baik karena hanya orang yang memiliki iman dan taqwa serta akhlak yang baik dapat dididik, diarahkan, dan berhasil dalam kehidupannya (Amrullah, 2017). Selain itu, pendidikan berkarakter merupakan bagian yang fundamental dalam membentuk manusia yang berkualitas (Jalil, 2012).

Sejak tahun 2013 semua mata pelajaran telah diwajibkan untuk melaksanakan pembelajaran berdasarkan kurikulum K13. Kurikulum ini bertujuan untuk menciptakan manusia indonesia yang kreatif, inovatif, proaktif, dan aktif yang diintegrasikan dengan pendidikan berkarakter (Mastur, 2017). Untuk mendukung kelancaran proses belajar mengajar berdasarkan kurikulum K13, harus dilengkapi dengan fasilitas yang sesuai. Salah satu fasilitas dalam pembelajaran adalah bahan ajar. Bahan ajar merupakan segala bentuk bahan yang digunakan untuk membantu guru/instruktur dalam melaksanakan kegitan belajar mengajar. Bahan ajar ini dapat dalam bentuk tertulis maupun bahan ajar tidak tertulis. Contoh bahan ajar tertulis diantaranya adalah buku dan modul (Depdiknas, 2008)

Buku adalah bahan tertulis yang menyajikan ilmu pengetahuan buah pikiran dari pengarangnya. Isi buku didapat dari berbagai cara misalnya: hasil penelitian, hasil pengamatan, aktualisasi pengalaman dan lain-lain. Akan tetapi beberapa buku belum memenuhi tuntutan dari kurikulum. Selain itu buku tidak bisa digunakan peserta didik untuk dapat belajar mandiri. Oleh sebab itu, pendidik dituntut untuk dapat mengembangakan suatu bahan ajar yang dapat memenuhi tuntutan kurikulum dan dapat digunakan secara mandiri oleh peserta didik, salah satu bahan ajar tersebut adalah modul

Modul adalah sebuah buku yang ditulis dengan tujuan agar peserta didik dapat belajar secara mandiri dengan bantuan guru seminimal mungkin (Depdiknas, 2008). Dalam mengembangkan modul dapat ditambahkan poin-poin yang dituntut dalam kurikulum 13, salah satu poin tersebut adalah pendidikan karakter. Pendidikan karakter adalah proses pemberian tuntunan kepada peserta didik untuk menjadi manusia seutuhnya yang berkarakter dalam dimensi hati, pikiran, raga, serta rasa dan karsa. Akan tetapi, masih banyak sekolah yang belum memasukan nilai-nilai karakter pada modul yang diberikan kepada peserta didik. Untuk itu, diperlukan penggembangan modul yang terintegrasi pendidikan karakter yang dapat membimbing peserta didik untuk berkarakter positif.

Subekti dan kawan-kawan (2016) telah berhasil mengembangkan modul Bahasa Indonesia bermuatan nilai karakter yang dapat membantu dosen dan mahasiswa dalam kegiatan belajar mengajar. Sedangkan, Ismawati dan kawan-kawan (2018) telah berhasil mengembangkan modul pendidikan karakter pada pelajaran IPS yang dapat meningkatkan hasil belajar siswa secara signifikan. Nilai-nilai karakter dapat dimasukan pada semua materi pada matapelajaran kimia. Salah satu materi dalam matapelajaran kimia yang dapat dihubungankan dengan pendidikan karakter adalah koloid. Pokok bahasan koloid tidak terbatas hanya konsep dan teori semata namun banyak nilai dan aplikasi dalam kehidupan sehari-hari. Berdasarkan permasalahan di atas mendorong penulis untuk melakukan penelitian pengembangan tentang "Pengembangan Modul Terintegrasi Pendidikan Karakter Pada Materi Koloid" 


\section{METODE PENELITIAN}

Penelitian pengembangan modul terintegrasi karakter pada pokok bahasan koloid dilakukan di Fakultas Keguruan dan Ilmu Pendidikan (FKIP). Waktu pengambilan data dilakukan pada bulan Februari-Oktober 2018. Penelitian ini dirancang dengan desain Reserch and Development (R\&D) yang terdiri atas tiga tahap define, design, dan development yang mengacu pada model 4-D.

A. Tahap Define

Merupakan tahap awal sebelum melakukan penelitian dan pengembangan untuk mengetahui kebutuhan awal dalam mengembangkan modul. Kegiatan pada tahap analisis meliputi: analisis awal akhir, analisis peserta didik, analisis konsep dan analisi tugas.

B. Tahap Design

Tahap design adalah tahap dimana data-data dari hasil survei kemudian disusun dan dikaitkan dengan modul pembelajaran yang akan dikembangkan.

C. Tahap development

Tahap development merupakan proses mengembangkan produk desain modul kimia terintegrasi karakter pada pokok bahasan koloid. Instrumen data yang digunakan yaitu, lembar validasi ahli materi, lembar angket respon guru kimia dan lembar angket respon siswa. Skala penilaian yang digunakan pada angket validasi dan respon guru adalah skala Likert, skala ini memberikan keleluasaan dalam menilai modul terintegrasi pendidikan karakter pada materi koloid, dengan alternatif jawaban sangat setuju (SS), setuju (S), cukup setuju (CS), tidak setuju (TS), dan sangat tidak setuju(STS) yang masing-masing diberikan skor berturut-turut, 5 (SS), 4 (S), 3 (CS), 2 (TS), dan 1 (STS). Setelah jumlah data dari validator di dapatkan, langkah selanjutnya adalah menentukan persentase penilaian validator dengan menggunakan rumus:

$$
P P V=\frac{\sum \text { jawaban validator }}{\sum \text { nilai tertinggi validator }} \times 100 \%
$$

Keterangan :

PPV

$\sum$ Jawaban Validator

$=$ Persentase Penilaian Validator

$\sum$ Nilai Tertinggi Validator

$=$ Jumlah total jawaban validator

$=$ Jumlah total nilai tertinggi validator

Tabel 1. Kriteria Interpretasi Skor Kelayakan Modul

\begin{tabular}{cc}
\hline Persentasi $(\%)$ & Keterangan \\
\hline 0 - 20 & Tidak Valid \\
$\mathbf{4 1}-\mathbf{4 0}$ & Kurang Valid \\
$\mathbf{6 1}-\mathbf{8 0}$ & Cukup Valid \\
$\mathbf{8 1 - 1 0 0}$ & Valid \\
\hline
\end{tabular}


Pada lembar tanggapan peserta didik menggunakan skala Guttman dengan pilihan jawaban iya dan tidak. Untuk pilihan ya diberikan skor 1, sedangkan untuk skor tidak diberikan skor 0. Setelah mendapat jumlah jawaban responden, langkah selanjutnya adalah menentukan persentase respon peserta didik dengan rumus :

$$
P R S=\frac{\text { Sjawaban responden }}{\sum \text { nilai terting gi responden }} \times 100 \%
$$

Keterangan :

$\begin{array}{ll}\text { PRS } & =\text { Persentase Respon Siswa } \\ \sum \text { Jawaban Responden } & =\text { Jumlah total jawaban responden } \\ \sum \text { Nilai Tertinggi Responden } & =\text { Jumlah total nilai tertinggi responden }\end{array}$

(Riduwan, 2009)

Tabel 2. Kriteria Skor Kelayakan Modul Oleh Peserta Didik

\begin{tabular}{cc}
\hline Nilai $(\%)$ & Kriteria \\
\hline $\mathbf{0 - 2 0}$ & Tidak baik \\
$\mathbf{2 1 - 4 0}$ & Kurang Baik \\
$\mathbf{4 1 - 6 0}$ & Cukup baik \\
$\mathbf{6 1 - 8 0}$ & Baik \\
$\mathbf{8 1 - 1 0 0}$ & Sangat baik \\
\hline
\end{tabular}

(Niswah, A., 2012)

\section{HASIL DAN PEMBAHASAN}

Model yang digunakan dalam penelitian adalah model 4-D dengan tahap-tahapnya sebagai berikut:

\section{A. Define (Tahap Pendefinisian)}

Pada tahap analisis ujung depan didapatkan permasalahan yaitu masih terbatasnya modul terintegrasi pendidikan karakter yang dapat membimbing peserta didik memiliki karakter. Peserta didik pengguna modul berusia rata-rata 16-17 tahun. Pada usia tersebut peserta didik terlatak tahap operasional formal dan mendekati intelektual yang maksimal. Tahap perkembangan kognitif memiliki peran yang signifikan dalam pembelajaran, yakni pentingnya memilih aktivitas belajar yang sesuai dengan usia dan perkembangan kognitifnya.

Tahap selanjutnya adalah analisi tugas yang akan menghasilkan materi yang disajikan di dalam modul dan nilai-nilai karakter sesuai dengan tuntutan silabus kurikulum K13, konsep-konsep utama yang akan dipelajari, serta indikator pencapaian kompetensi yang akan dicapai.

\section{B. Design (Tahap Perencanaan)}


Dari analisis yang telah dilakukan, dilanjutkan dengan pembuatan outline modul berdasarkan aturan dari Depdiknas (2018). Hasil dari tahap design antara lain:

1. Rancangan pendahuluan modul

Pada rancangan pendahuluan modul menghasilkan: Kompetensi Dasar, Indikator Pencapaian Kompetensi, tujuan pembelajaran, deskripsi modul dan petunjuk penggunaan modul.

2. Pembelajaran

Pada bagian pembelajaran modul terdiri dari materi yang akan dipelajari, nilai-nilai karakter disetiap pertemuan, latihan, ringkasan materi, penilaian diri soal uji pemahaman.

3. Penutup

Pada bagian penutup terdiri dari: kesimpulan, evaluasi, daftar pustaka, kunci jawaban tugas.

\section{Development (Tahap Pengembangan)}

Pada tahap pengembangan dilakukan beberapa langkah, yaitu:

1. Pembuatan Modul

Pada tahap ini dilakukan penyusunan dari hasil tahap design secara sistematis sehingga dihasilkan modul yang direncanakan untuk proses pembelajaran. Bentuk desain halaman muka modul yang dikembangkan ditunjukkan pada Gambar 1.

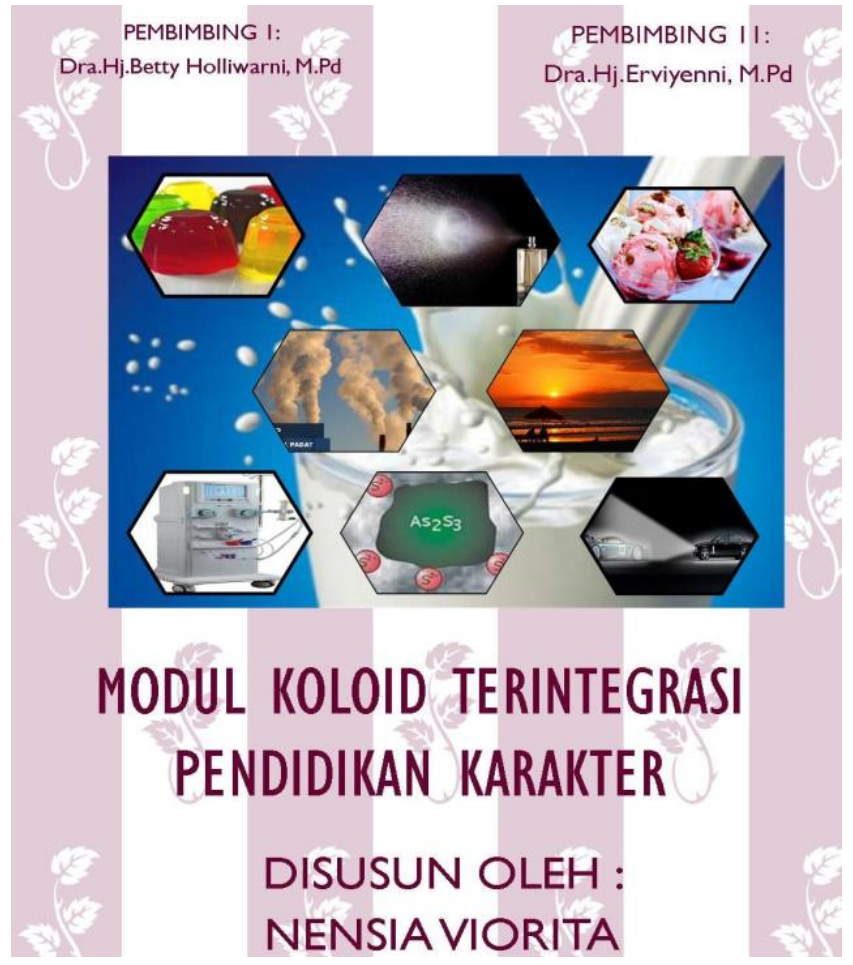

Gambar 1. Modul koloid terintegrasi pendidikan karakter

2. Validasi Produk

Validasi meliputi 4 aspek, yaitu aspek kelayakan isi, kebahasaan, penyajian dan kegrafisan dan validasi dilakukan 1-2 kali sehingga dinyatakan valid dan dapat digunakan. 
Pada validasi pertama, validator menyarankan untuk memperbaiki isi modul yang terkait dengan tujuan pembelajaran, penggunaan kalimat efektif sesuai dengan EYD, serta menyarankan untuk menambahkan gambar yang terkait dengan konsep-konsep pada pokok bahasan koloid. Hasil akhir dari keempat aspek yang dinilai tersebut sebagai berikut:

a. Aspek Kelayakan Isi

Hasil akhir validasi pada aspek kelayakan isi dapat dilihat pada Tabel 3.

Tabel 3. Hasil Akhir Validasi Pada Aspek Kelayakan Isi

\begin{tabular}{llcc}
\hline No & \multicolumn{1}{c}{ Pernyataan } & Skor (\%) & Kriteria \\
\hline $\mathbf{1}$ & $\begin{array}{l}\text { Isi modul sesuai dengan Kompetensi } \\
\text { Inti, KI 1,KI 2, KI 3 dan KI 4 }\end{array}$ & 100 & Sangat Valid \\
$\mathbf{2}$ & $\begin{array}{l}\text { Isi modul sesuai dengan Kompetensi } \\
\text { Dasar }\end{array}$ & 100 & Sangat Valid \\
$\mathbf{3}$ & $\begin{array}{l}\text { Materi yang disajikan sesuai dengan } \\
\text { tujuan pembelajaran }\end{array}$ & 86,67 & Sangat Valid \\
$\mathbf{4}$ & $\begin{array}{l}\text { Modul memperlihatkan nilai-nilai } \\
\text { karakter positif }\end{array}$ & 93,33 & Sangat Valid \\
$\mathbf{5}$ & $\begin{array}{l}\text { Isi modul membimbing peserta didik } \\
\text { menimbulkan karakter-karakter positif }\end{array}$ & 93,33 & Sangat Valid \\
\hline & Presentase (\%) Skor & $\mathbf{9 4 , 6 7}$ & Sangat Valid \\
\hline
\end{tabular}

Skor rata-rata validasi pada aspek kelayakan isi adalah 94,67\% dengan kategori sangat valid. Pada Tabel 3 komponen 1 dan 2 mendapat nilai $100 \%$. Menurut validator materi yang disajikan sudah sesuai dengan KI dan KD. Komponen 4 dan 5 mendapat skor 93,33\% karena nilai-nilai karakter yang disajikan sudah bagus tetapi masih ada kekurang seperti beberapa nilai karakter yang disajikan belum terkait dengan materi yang dipaparan. Pada komponen 3 mendapat skor 86,67\% karena ada beberapa materi pada pertemuan belum sempurna sesuai dengan tujuan yang diinginkan.

b. Aspek Kebahasaan

Pada aspek kebahasaan ada 4 poin penilaian. Hasil akhir pada aspek kebahasaan dapat dilihat pada Tabel 4 .

Tabel 4. Hasil Akhir Validasi Aspek Kebahasaan

\begin{tabular}{llcc}
\hline No & \multicolumn{1}{c}{ Peryataan } & Skor (\%) & Kriteria \\
\hline $\mathbf{1}$ & Bahasa yang digunakan efektif & 80,00 & Sangat Valid \\
$\mathbf{2}$ & Tulisan dan bahasa dalam modul dapat dibaca & 86,67 & Sangat Valid \\
$\mathbf{3}$ & Modul memiliki informasi yang jelas & 93,33 & Sangat Valid \\
$\mathbf{4}$ & $\begin{array}{l}\text { Modul menggunakan bahasa sesuai dengan } \\
\text { tingkat kemampuan peserta didik }\end{array}$ & 86,67 & Sangat Valid \\
\hline & Skor Rata-Rata & $\mathbf{8 6 , 6 7}$ & Sangat Valid \\
\hline
\end{tabular}

Berdasarkan Tabel 4, kompenen 1 mendapat skor $80 \%$ karena bahasa yang digunakan kurang efektif, seperti masih ada pengulangan kata di dalam modul. Menurut Daryanto(2013) bahasa yang digunakan dalam modul adalah bahasa yang efektif, sederhana 
dan komunikatif. Komponen 2 mendapat skor 86,67\% karena ada beberapa bagian di dalam modul yang sulit dibaca. Hal ini disebabkan karena ukuran huruf yang cukup kecil. Menurut Daryanto (2013) ukuran dan bentuk mempengaruhi keterbacaan modul dan gunakan bentuk dan ukuran huruf yang proposional. Komponen 4 juga mendapat skor 86,67\% bahasa masih kurang sesuai dengan tingkat kemampuan peserta didik. Komponen 4 mendapat skor 93,33\% karena sumber informasi yang terdapat di dalam modul sudah jelas.

c. Aspek Penyajian

Terdapat 2 komponen penilaian. Hasil akhir dari validasi pada aspek kegrafisan dapat dilihat pada Tabel 5.

Tabel 5. Hasil Akhir Validasi Aspek Penyajian

\begin{tabular}{|c|c|c|c|}
\hline No & Pernyataan & Skor (\%) & Kriteria \\
\hline 1 & $\begin{array}{l}\text { Penyajian sesuai dengan materi pokok dalam } \\
\text { silabus K13, yaitu: } \\
\text { a. Jenis koloid } \\
\text { b. Sifat koloid } \\
\text { c. Pembuatan koloid } \\
\text { d. Peranan koloid dalam kehidupan sehari- } \\
\text { hari dan industri }\end{array}$ & 93,33 & Sangat Valid \\
\hline 2 & $\begin{array}{l}\text { Modul memiliki struktur yang lengkap (judul, } \\
\text { petunjuk belajar (petunjuk siswa atau pendidik), } \\
\text { kompetensi yang akan dicapai, informasi } \\
\text { pendukung, latihan, petunjuk kerja atau dapat pula } \\
\text { berupa lembar kerja (LK), dan evaluasi) }\end{array}$ & 100 & Sangat Valid \\
\hline & Skor Rata-Rata & 96,67 & Sangat Valid \\
\hline
\end{tabular}

Berdasarkan Tabel 5 komponen 1 mendapat skor 93,33\% karena contoh peranan koloid dalam kehidupan sehari-hari masih kurang. Komponen 2 mendapat skor $100 \%$ menurut validator modul sudah memiliki struktur yang lengkap.

c. Aspek Kegrafisan

Terdapat 6 komponen penilaian pada aspek kegrafisan. Hasil akhir validasi dari aspek kegrafisan dapat dilihat pada Tabel 6.

Tabel 6. Hasil Akhir Validasi Aspek Kegrafisan

\begin{tabular}{|c|c|c|c|}
\hline NO & Pernyataan & Skor $(\%)$ & Kriteria \\
\hline 1 & $\begin{array}{l}\text { Modul menggunakan jenis dan ukuran huruf yang } \\
\text { baik dan menarik }\end{array}$ & 86,67 & Sangat Valid \\
\hline 2 & Modul memiliki lay out/tata letak yang menarik & 80 & Sangat Valid \\
\hline 3 & $\begin{array}{l}\text { Modul memiliki ilustrasi/gambar yang baik dan } \\
\text { berhubungan dengan konsep }\end{array}$ & 93,33 & Sangat Valid \\
\hline \multirow[t]{2}{*}{4} & Modul memiliki desain tampilan yang menarik & 93,33 & Sangat Valid \\
\hline & Skor Rata-Rata & 88,33 & Sangat Valid \\
\hline
\end{tabular}

Berdasarkan Tabel 6 komponen 2 mendapat nilai 80\% karena lay out modul masih kurang rapi dan kompenen 1 mendapat skor $86,67 \%$ hal ini disebabkan ukuran jenis dan ukuran tulisan yang kurang proporsional. Komponen 3 dan 4 mendapat skor yang sama, yaitu 93,33\% ketiga validator berpendapat bahwa desain modul sudah menarik dan gambar 
yang digunakan sudah sesuai dan berhubungan dengan konsep. Menurut Daryanto (2013) daya tarik modul dapat ditempatkan di beberapa bagian seperti:

1) Bagian sampul (cover) depan, dengan mengkombinasikan warna, gambar, bentuk dan ukuran huruf yang serasi.

2) Bagian isi modul dengan menempatkan ransangan-ransangan berupa gambar atau ilustrasi.

3) Tugas dan latihan dikemas sedemikian rupa sehingga menarik.

Hasil rekap skor rata-rata validasi modul dapat dilihat pada Gambar 2.

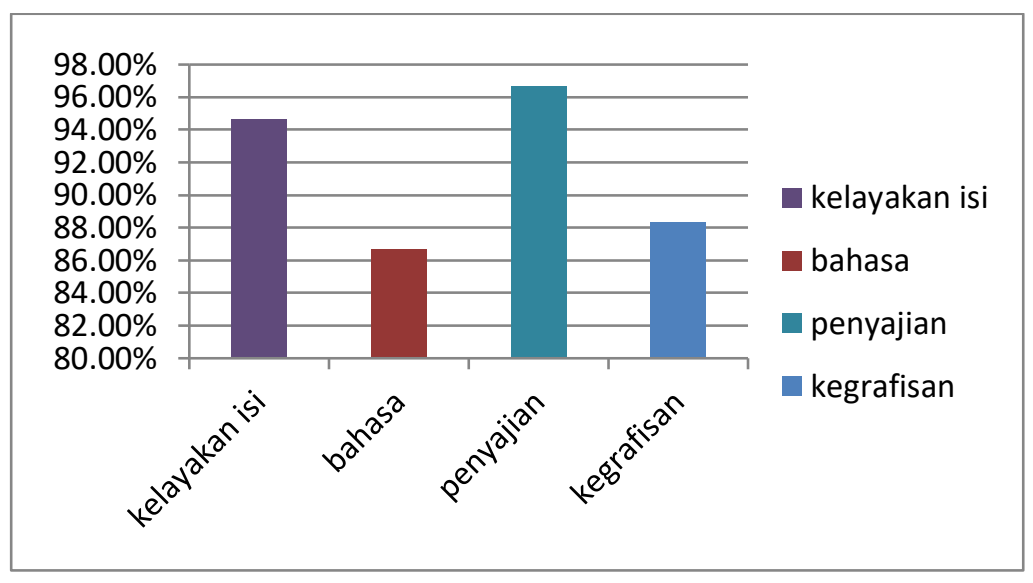

Gambar 2. Grafik Nilai Rata-Rata Validasi

\section{Uji Terbatas}

Uji terbatas dilakukan jika modul yang dikembangkan dinyatakan valid oleh tim validator. Uji terbatas dilakukan oleh 2 orang guru kimia dan 30 orang peserta didik. Hasil penilaian guru dari SMAN 5 Pekanbaru dan guru MA Darel Hikmah dijumlahkan dan dirataratakan hasil rata-rata penilaian guru adalah 95,83\%. Saran dari guru SMAN 5 Pekanbaru latihan dan soal uji kemampuan dikemas semenarik mungkin dan soal untuk C3 keatas ditambahkan lagi. Penilaian guru mata pelajaran kimia MA Darel Hikmah terlalu banyak penjelasan sehingga isi modul terlihat lebih ramai dan menyarankan untuk menampilkan soal-soal HOTS pada modul. Hasil dari uji terbatas juga dilakukan pada peserta didik. responden berjumlah 30 orang. Presentasi rata-rata angket peserta didik terhadap modul terintegrasi pendidikan karakter pada materi koloid adalah 97,17\%. Secara umum, peserta didik menilai bahwa modul koloid terintegrasi karakter menarik karena memiliki tampilan yang bagus dan mudah dimengerti sehingga dapat membantu untuk memahami materi koloid. Gambar-gambar yang disajikan didalam modul, desain dan warna-warna yang menarik membuat modul terlihat menarik sehingga belajar tidak membosankan.

\section{KESIMPULAN}

Modul terintegrasi pendidikan karakter pada materi koloid untuk kelas XI SMA/MA yang dikembangkan sudah valid memenuhi aspek kelayakan isi 94,67\%, penyajian 96,67\%, kebahasaan $86,67 \%$, dan kegrafisan $88,33 \%$ dengan skor rata-rata validasi modul adalah 
91,59\%, sehingga modul dapat digunakan dalam proses pembelajaran. Uji terbatas yang dilakukan di SMAN 5 Pekanbaru dan SMA Dareel Hikmah mendapatkan kriteria sangat baik/ sangat praktis dengan skor rata-rata dari peserta didik adalah $97,17 \%$ dan skor ratarata dari guru adalah $95,83 \%$

\section{DAFTAR PUSTAKA}

Amrullah, A., Hadisaputo, S., dan Supardi, K.I. 2017. Pengembangan Modul CHEMIRELIGIOUSA Terintegrasi Pendidikan Karakter Bervisi SETS, Jurnal Inovasi Pendidikan Kimia. 11(1):1872-1883.

Daryanto. 2013. Menyusun Modul Bahan Ajar Untuk Persiapan Guru Dalam Mengajar. Gava Media. Yogyakarta.

Depdiknas. 2008. Panduan Pengembangan Bahan Ajar. Direktorat Pembinaan Sekolah Menengah Atas. Jakarta

Depdiknas. 2018. Penyusunan Modul, Direktorat Pembinaan Sekolah Menengah Atas, Jakarta

Ismawati, M., Tegeh, I.M., dan Jampel, I.N. 2018. Pengembangan modul berorientasi pendidikan karakter pada mata pelajaran ips siswa kelas VII Semester Ganjil Tahun Pelajaran 2018/2019 di SMP Muhammadiyah 2 Singaraja. Jurnal Jurusan Teknologi Pendidikan. 9(2):291-300.

Jalil, A. 2012. Karakter pendidikan untuk membentuk pendidikan karakter. Nadwa Jurnal Pendidikan Islam. 6(2):175-192.

Mastur. 2017. Implementasi kurikulum 2013 dalam pelaksanaan pembelajaran di SMP. Jurnal Inovasi Teknologi Pendidikan. 4(1):50-64.

Niswa, A. 2012. Pengembangan bahan ajar mendengarkan berbasis video interaktif bermedia flash kelas VII SMPN 1 Kedamean. Jurnal Bahasa dan Sastra Indonesia. 1(1): $1-18$

Subekti, T., Alawiyah, E.M.L., dan Sumarlam. 2016. Pengembangan Modul Bahasa Indonesia Bermuatan Nilai Karakter Kebangsaan bagi Mahasiswa PGSD. Profesi Pendidikan Dasar. 3(2):92-101.

Trianto. 2011. Mendesain Model Pembelajaran Inovatif-Progresif. Kencana Prenada Media Group. Jakarta 